\title{
Effect of corticosteroids on sputum sol-phase protease inhibitors in chronic obstructive pulmonary disease
}

\author{
J WIGGINS, JA ELLIOTT, RD STEVENSON, RA STOCKLEY
}

From the General Hospital, Birmingham; the Immunodiagnostic Research Laboratory, University of Birmingham; and the Western Infirmary, Glasgow

ABSTRACT Corticosteroids caused a reduction in the ratio of sol-phase sputum concentration to serum concentration of albumin in 12 patients with chronic obstructive bronchitis, suggesting a 은 reduction in protein transudation. Alpha-1-antitrypsin values followed the same pattern as those of albumin in both the control and treatment periods, confirming the similar behaviour of the two $\mathcal{D}_{\mathbb{D}}$ proteins. The $\alpha_{1}$-antichymotrypsin ratios were on average three times higher than those of $\frac{\vec{D}}{\mathbb{D}}$ albumin in the control period, confirming the presence of local mechanisms in the lung for 3 preferentially concentrating this protein. The sputum-to-serum ratio of $\alpha_{1}$-antichymotrypsin, 은 however, rose during steroid treatment with the result that there was a selective increase in this $\overrightarrow{0}$ protease inhibitor, which may be of potential benefit to such patients.

Uncontrolled enzyme activity within the lung is potentially harmful to the bronchial mucosa and cilia $^{1}$ and has been implicated in the pathogenesis of emphysema. ${ }^{2}$ The serum and pulmonary secretions, however, contain several enzyme inhibitors that may protect the tissues from enzyme-induced damage.

The main serum and alveolar inhibitor of proteolytic enzymes is $\alpha_{1}$-antitrypsin ${ }^{3}$ and severe deficiency of this protein is associated with the development of pulmonary emphysema. ${ }^{4}$ This association has led to the hypothesis that emphysema in subjects with normal serum $\alpha_{1-}$ antitrypsin concentrations arises as a result of an imbalance between the enzymes and inhibitors within the lung such that enzyme activity persists. ${ }^{3}$ Any factor therefore that disturbs the balance between enzymes and inhibitors within the lung may be a major determinant of subsequent disease. Recently it has been shown that danazol can increase the $\alpha_{1}$-antitrypsin concentration in serum ${ }^{5}$ and that this is of potential benefit in protecting the lung. The effect of other, more commonly prescribed therapeutic agents, however, has received little attention.

Corticosteroids are frequently given to patients with chronic bronchitis and emphysema in the

Address for reprint requests: Dr RA Stockley, General Hospital, Steelhouse Lane, Birmingham B4 6NH. absence of reversible airflow obstruction, despite the general lack of evidence of therapeutic benefit. ${ }^{6}$ Chranowski and his associates, however, suggested $\stackrel{\circ}{\Phi}$ that steroids may have had a beneficial effect on lung destruction in a study of a small group of $\frac{0}{3}$ patients with emphysema.?

The purpose of the present study was to investigate the effect of corticosteroid treatment on the concentration of two proteolytic enzyme inhibitors, $\alpha_{1}$-antitrypsin and $\alpha_{1}$-antichymotrypsin, in both the serum and the secretions from a group of patients with chronic obstructive bronchitis. On theoretical grounds we were particularly interested to see $\dot{\delta}$ whether the anti-inflammatory properties of steroids might reduce protein (and hence $\alpha_{1}$-antitrypsin) 0 transudation from serum to the lung secretions.

\section{Methods}

Fourteen patients with chronic obstructive bron- N chitis $^{8}$ were studied in the stable clinical state (aver- N age age $56 \cdot 2$ years, $S D \pm 11.0$ years). All were cur- $\sigma$ rent smokers and nine were men. All had severe

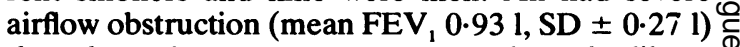
that showed no acute response to bronchodilator $\stackrel{\mathbb{D}}{\rightarrow}$ treatment.

The patients were admitted to hospital for the $\frac{0}{0}$ period of study at least four weeks after any previous infective episode. Placebo was given for five $\frac{\vec{D}}{\mathrm{D}}$ 652 
days followed by prednisolone ( $40 \mathrm{mg}$ daily) for one week. Sputum was collected daily over a six-hour period for the first and last five days of the study. The sputum was centrifuged at $100000 \mathrm{~g}$ for 90 minutes and the sol phase was removed and stored at $-70^{\circ} \mathrm{C}$ until analysis. Venous blood was taken on each sample day during the period of sputum collection and the serum was also stored at $-70^{\circ} \mathrm{C}$.

All proteins were measured by standard rocket immunoelectrophoresis techniques with monospecific antisera prepared in the immunodiagnostic research laboratory, University of Birmingham. The results were expressed as percentages of a standard reference serum $(100 \% \equiv 44400 \mathrm{mg} / \mathrm{l}$ albumin, $2040 \mathrm{mg} / \mathrm{l} \alpha_{1}$-antitrypsin, and $429 \mathrm{mg} / \mathrm{l} \alpha_{1}$-antichymotrypsin). The main statistical analysis was performed on the sputum-to-serum protein concentration ratios as this overcomes individual differences in serum concentrations of the acute-phase proteins such as $\alpha_{1}$-antitrypsin and $\alpha_{1}$-antichymotrypsin. ${ }^{9}$ The significance of any change was assessed by the Wilcoxon rank sum test for paired data with a single-tailed test for albumin and $\alpha_{1}$ antitrypsin and a two-tailed test for $\alpha_{1}$-antichymotrypsin.

\section{Results}

Two patients developed acute chest infections during the period of study and their results were omitted from further analysis. The remaining data were incomplete on days 5 and 12 and these results were not included in statistical analysis (data for eight patients on day 5 are shown in the table and figures).

No significant change in $\mathrm{FEV}_{1}$ was noted during

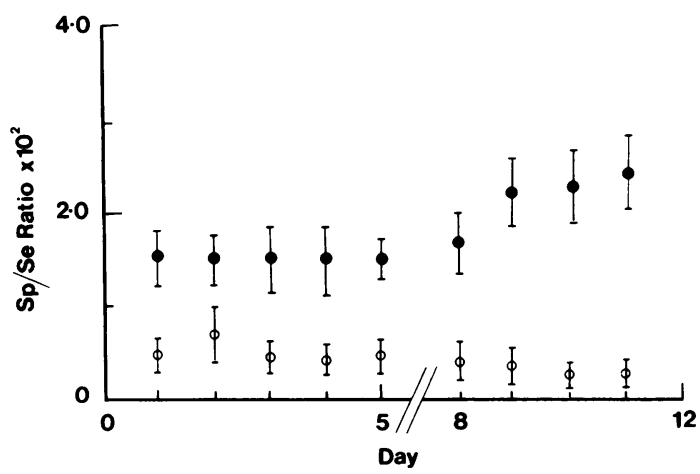

Fig 1 Sputum-to-serum concentration ratios for $\alpha_{1}$-antichymotrypsin (solid circles) and albumin (open circles) during placebo (days 1-5) and steroid treatment (days 8-11). Each point represents the average results for all patients for the collection days (value for day 5 is from 8 patients only). The bars represent \pm 1 SEM. the study and treatment had no effect on the mean serum values of any protein. The average serum and sputum protein concentrations and sputum-toserum protein concentration ratios are summarised in the table.

Albumin Individual sputum-to-serum ratios varied from $0.11 \times 10^{-2}$ to $1.28 \times 10^{-2}$. During the placebo period, however, the average daily value for the group as a whole was relatively constant and similar to our previous results. ${ }^{10}$ The average daily ratios for the whole group did not differ significantly from one another during the placebo period. Data for the first day of collection during steroid treatment (day 8, the third day of treatment) were similar to the control data. By the following day (day 9, the fourth day) the average sputum-to-serum albumin ratio had fallen but the difference just failed to reach significance $(p<0.1,>0.05)$. The results obtained for the fifth and sixth days of treatment (table), however, were significantly lower than the first four days of placebo treatment, when complete data were available $(\mathrm{p}<0.05)$.

Alpha-1-antitrypsin The individual data for $\alpha_{1}$-antitrypsin were more variable in the placebo period than the data for albumin but tended to follow a similar trend, values falling during corticosteroid treatment. The lowest sputum-to-serum

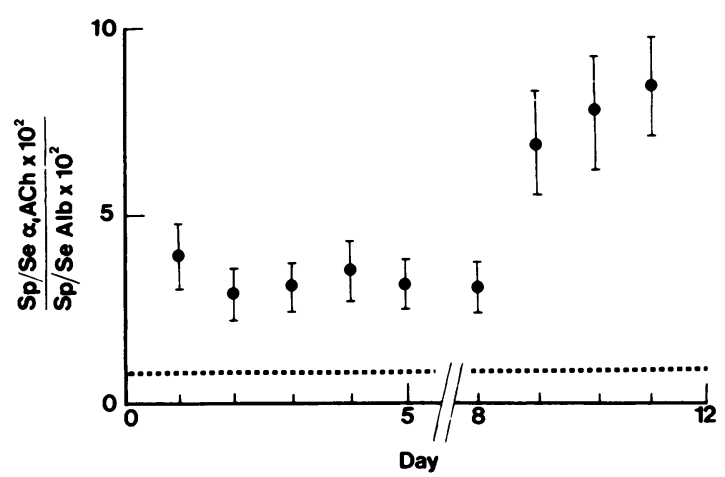

Fig 2 The sputum-to-serum concentration ratio for $\alpha_{1}$-antichymotrypsin corrected for the corresponding albumin ratio during placebo (days 1-5) and steroid treatment (days 8-11). Each point is the average value for a day's collection and the bars represent \pm 1 SEM. The dotted line indicates expected values if $\alpha_{1}$-antichymotrypsin in sputum sol phase were solely derived from serum by simple transudation (the difference in molecular size between albumin and $\alpha_{1}$-antichymotrypsin ${ }^{9}$ being taken into account). Values above this line suggest a "local" mechanism for preferentially concentrating $\alpha_{1}$-antichymotrypsin. 
Serum and sol-phase sputum protein concentrations and concentration ratios in 12 patients with chronic obstructive pulmonary disease (mean values with 1 standard deviation in parenthesis)

\begin{tabular}{|c|c|c|c|c|c|c|c|c|c|c|}
\hline & \multirow[b]{2}{*}{ Day: } & \multicolumn{5}{|c|}{ Placebo } & \multicolumn{4}{|c|}{ Treatment } \\
\hline & & $I$ & 2 & 3 & 4 & $5^{*}$ & 8 & 9 & 10 & 11 \\
\hline 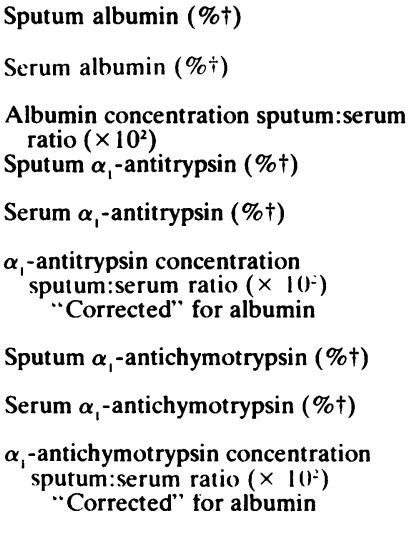 & & $\begin{array}{l}0 \cdot 35 \\
(0 \cdot 17) \\
85 \cdot 2 \\
(24 \cdot 2) \\
0 \cdot 50 \\
(0 \cdot 33) \\
0 \cdot 63 \\
(0 \cdot 39) \\
113 \cdot 7 \\
(38 \cdot 1) \\
0 \cdot 59 \\
(0 \cdot 39) \\
1 \cdot 24 \\
(0 \cdot 68) \\
3 \cdot 04 \\
(2 \cdot 09) \\
211 \cdot 3 \\
(71 \cdot 2) \\
1.42 \\
(0 \cdot 95) \\
3 \cdot 92 \\
(2 \cdot 77)\end{array}$ & $\begin{array}{l}0.63 \\
(0.85) \\
89.5 \\
(29.2) \\
0.71 \\
(0.86) \\
0.90 \\
(1.02) \\
123.7 \\
(37.6) \\
0.68 \\
(0.62) \\
1 \cdot 16 \\
(0.35) \\
2.93 \\
(2.08) \\
213.2 \\
(80.7) \\
1.36 \\
(0.87) \\
2.94 \\
(1.93)\end{array}$ & $\begin{array}{l}0.41 \\
(0.21) \\
88.7 \\
(24.9) \\
0.48 \\
(0.30) \\
0.70 \\
(0.46) \\
127.3 \\
(30.5) \\
0.55 \\
(0.35) \\
1.20 \\
(0.61) \\
2.82 \\
(1.80) \\
203.2 \\
(65.6) \\
1.35 \\
(0.89) \\
3.13 \\
(1.97)\end{array}$ & $\begin{array}{l}0.39 \\
(0 \cdot 19) \\
86.2 \\
(20.3) \\
0.46 \\
(0.22) \\
0.65 \\
(0.52) \\
137.9 \\
(51 \cdot 1) \\
0.47 \\
(0.34) \\
1.04 \\
(0.48) \\
2.90 \\
(2.19) \\
199.0 \\
(56.1) \\
1.38 \\
(0.88) \\
3.51 \\
(2.03)\end{array}$ & $\begin{array}{l}0.45 \\
(0.26) \\
94.6 \\
(20 \cdot 3) \\
0.48 \\
(0.31) \\
0.68 \\
(0.51) \\
134 \cdot 3 \\
(28 \cdot 0) \\
0.49 \\
(0.32) \\
1 \cdot 13 \\
(0.38) \\
3 \cdot 00 \\
(1 \cdot 55) \\
207.0 \\
(51 \cdot 2) \\
1.40 \\
(0.45) \\
3.26 \\
(1.09)\end{array}$ & $\begin{array}{l}0.36 \\
(0.20) \\
89.7 \\
(18.6) \\
0.45 \\
(0.28) \\
0.48 \\
(0.36) \\
116.8 \\
(22.4) \\
0.43 \\
(0.33) \\
1.02 \\
(0.45) \\
3.48 \\
(2.50) \\
191.8 \\
(37.8) \\
1.58 \\
(1.19) \\
3.07 \\
(1.20)\end{array}$ & $\begin{array}{l}0.33 \\
(0.20) \\
88 \cdot 6 \\
(21 \cdot 1) \\
0 \cdot 36 \\
(0 \cdot 20) \\
0.48 \\
(0 \cdot 29) \\
114 \cdot 7 \\
(20 \cdot 4) \\
0.40 \\
(0.20) \\
1 \cdot 19 \\
(0.47) \\
4.46 \\
(2 \cdot 66) \\
197.4 \\
(51 \cdot 5) \\
2 \cdot 30 \\
(1 \cdot 50) \\
6.95 \\
(4 \cdot 82)\end{array}$ & $\begin{array}{l}0.32 \\
(0 \cdot 18) \\
94 \cdot 1 \\
(21 \cdot 0) \\
0 \cdot 33 \\
(0 \cdot 18) \\
0.47 \\
(0 \cdot 31) \\
117.6 \\
(25 \cdot 9) \\
0 \cdot 38 \\
(0.20) \\
1 \cdot 24 \\
(0.55) \\
4 \cdot 64 \\
(3 \cdot 20) \\
201 \cdot 5 \\
(50 \cdot 1) \\
2 \cdot 39 \\
(1.78) \\
7.71 \\
(5.05)\end{array}$ & $\begin{array}{l}0 \cdot 33 \\
(0 \cdot 21) \\
93 \cdot 6 \\
(17 \cdot 5) \\
0 \cdot 34 \\
(0 \cdot 20) \\
0 \cdot 49 \\
(0 \cdot 34) \\
117 \cdot 1 \\
(26 \cdot 8) \\
0 \cdot 43 \\
(0 \cdot 26) \\
1 \cdot 36 \\
(0 \cdot 55) \\
5 \cdot 24 \\
(3 \cdot 57) \\
196.6 \\
(40 \cdot 0) \\
2 \cdot 57 \\
(1 \cdot 57) \\
8 \cdot 48 \\
(4 \cdot 26)\end{array}$ \\
\hline
\end{tabular}

${ }^{*}$ Data on only eight patients included.

†Percentage of standard serum (see under "Methods").

ratios were obtained on the fourth and fifth days of treatment (days 9 and 10). The values obtained on these days were significantly lower than on control day $2(\mathrm{p}<0.05)$ but the difference just failed to reach statistical significance when compared with the results for days 1 and $3(p<0 \cdot 1,>0 \cdot 05)$. The average sputum-to-serum concentration ratios for $\alpha_{1}$-antitrypsin were similar to those of albumin during both placebo and treatment periods and "correction" (division of sputum-to-serum concentration ratios of $\alpha_{1}$-antitrypsin by those of albumin) gave values close to 1 during both periods.

Alpha-1-antichymotrypsin Serum $\alpha_{1}$-antichymotrypsin concentrations were slightly higher than those of the control serum but similar to values found previously in patients with stable chronic obstructive bronchitis. " The average sputum-to-serum concentration ratios for $\alpha_{1}$-antichymotrypsin were about three times those of albumin during the placebo period (see table and fig 1). During this period the ratios did not change significantly. After the third day of corticosteroid treatment the ratios rose and were significantly greater than the results from the first four placebo days $(2 p<0.05)$ by the fourth day of treatment (day 9). The values for the fifth and sixth days of treatment (days 10 and 11) remained significantly higher than any of the first four days of placebo treatment when data collection had been complete $(2 p<0 \cdot 01)$.

The difference in behaviour between $\alpha_{1}$ - antichymotrypsin and albumin is emphasised by "correction" for the corresponding albumin ratios (table and fig 2).

\section{Discussion}

Albumin is thought to enter the bronchial secretions by diffusion alone and changes in its sputum-toserum ratio may reflect changes in the degree of inflammation in the bronchial tree. ${ }^{9}$ During corticosteroid treatment the sputum-to-serum concentration ratios of albumin fell, which would be consistent with a reduction in inflammation. Alpha-1antitrypsin is of almost identical molecular size to albumin and behaves similarly, entering the secretions by simple transudation. Previous studies in our laboratory had shown their similar behaviour in the sol-phase of sputum in chronic obstructive bronchitis.9 The present study adds support to this hypothesis with similar ratios of sol-phase-sputum concentration to serum concentration for $\alpha_{1-} N$ antitrypsin and albumin during the placebo period and similar changes during corticosteroid treatment. Again the results suggest a reduction in protein transudation because of a decrease in mucosal inflammation. An alternative explanation might be an increase in dilutional factors, as a result either of contamination with greater quantities of saliva or of increased fluid content of the sol-phase during corticosteroid treatment. The results for $\alpha_{1-}$ 
antichymotrypsin, however, make this possibility less likely.

Alpha-1-antichymotrypsin is a slightly larger molecule than albumin and because the ratio of sol-phase sputum concentration to serum concentration of proteins derived solely from serum is affected by the protein size 9 it should have a lower ratio than albumin. The current results show a sputum-toserum ratio about three times higher for $\alpha_{1^{-}}$ antichymotrypsin than for albumin and confirm our previous findings of a preferential concentration of this protein in the secretion as a result of local mechanisms. ${ }^{911}$ The results are summarised in the table and in figure 1.

If the changes for $\alpha_{1}$-antitrypsin and albumin were purely dilutional, a similar effect would be seen for all proteins and the results for $\alpha_{1}$-antichymotrypsin should also fall. 9 The opposite occurred, however, with a rise in sputum-to-serum concentration ratios during corticosteroid treatment (fig 1 and table). The different behaviour of $\alpha_{1}$-antichymotrypsin and albumin is emphasised in figure 2 , where the sputum-to-serum concentration ratios of $\alpha_{1-}$ antichymotrypsin are divided by the corresponding albumin results. The overall effect is a greater selective increase in $\alpha_{1}$-antichymotrypsin concentration in the secretions during steroid treatment. This may reflect an increase in "local production" or selective transport, or alternatively a reduction in pulmonary catabolism of $\alpha_{1}$-antichymotrypsin during corticosteroid treatment. Further studies will be necessary, however, to clarify these points.

The time course of the response to corticosteroids that we observed is of interest. When such patients have reversible airflow obstruction the maximum physiological response is usually found in the first eight days of treatment. ${ }^{12}$ The present study shows that in the absence of such a physiological response a change in the sol-phase protein content may occur as early as three days from the start of treatment and is clearly demonstrable by the fourth day. It therefore seems likely that when a response to steroid treatment, either physiological or biochemical, is sought in patients with chronic bronchitis and emphysema the therapeutic trial need last no more than 7-10 days. Nevertheless, the effects of the biochemical response on slowly progressive diseases such as bronchitis and emphysema could only be determined by continued study on a large group of patients over many years.

In conclusion, sputum-to-serum concentrations for albumin and $\alpha_{1}$-antitrypsin fell during corticosteroid treatment, which is consistent with reduced transudation from serum. The reduction in transudation may decrease the effective inhibitor screen to proteolytic enzymes such as elastase within the lung and may be potentially harmful. The importance of this observation is, however, difficult to assess fully without consideration of the effect of corticosteroids on the proteolytic enzymes or the complexing between enzyme and inhibitor within the lung. Corticosteroids may theoretically reduce the activity of these enzymes within lung secretions by stabilisation of lysosomal membranes of neutrophils taking part in the inflammatory response. ${ }^{13}$ Further studies on the balance between the enzyme and inhibitor are warranted.

The sputum-to-serum concentration ratios of $\alpha_{1}$-antichymotrypsin rose during corticosteroid treatment. The implications of this finding are not clear, but $\alpha_{1}$-antichymotrypsin is known to inhibit cathepsin $G$ and bacterial proteases ${ }^{14}$ and steroid treatment may increase protection against these proteolytic enzymes, which could be of benefit to some patients, particularly those with recurrent bacterial infections.

This work was supported by the West Midlands Regional Health Authority and the Medical Research Council. One of us (JW) was in receipt of a Sheldon research fellowship. We would like to thank Miss $\mathbf{J}$ Downs for her typing.

\section{References}

' Tegner H, Ohlsson K, Toremalm NG, van Mecklenberg C. Effect of human leucocyte enzymes on tracheal mucosa and its mucociliary activity. Rhinology 1979; 17:199-206.

${ }^{2}$ Eriksson S. Protease and protease inhibitors in chronic obstructive lung disease. Acta Med Scand 1978;203; 449-55.

${ }^{3}$ Gadek JE, Hunninghake GW, Fells GA, et al. Evaluation of the protease-antiprotease theory of human destructive lung disease. Bull Europ Physiopath Resp 1980;16, suppl:27-40.

${ }^{4}$ Eriksson S. Studies in alpha ${ }_{1}$ antitrypsin deficiency. Acta Med Scand 1965;177 suppl:1-85.

${ }^{5}$ Gadek J, Fulmer JD, Gelfand JA, et al. Danazol induced augmentation of serum alpha $a_{1}$ antitrypsin levels in individuals with marked deficiency of this antiprotease. J Clin Invest 1980;66:82-7.

- Sahn SA. Corticosteroids in chronic bronchitis and pulmonary emphysema. Chest 1978;73:389-96.

${ }^{7}$ Chranowski P, Keller S, Carreta J, Mandl I, Turino GM. Elastin content of normal and emphysematous lung parenchyma. Am J Med 1980;69:351-9.

${ }^{8}$ Medical Research Council Committee on the Aetiology of Chronic Bronchitis. Definition and classification of chronic bronchitis. Lancet 1965;i:775-9.

9 Stockley RA, Mistry M, Bradwell AR, Burnett D. A study of plasma proteins in the sol phase of sputum from patients with chronic obstructive bronchitis. Thorax 1979;34:777-82. 
${ }^{10}$ Stockley RA, Burnett D. Alpha, antitrypsin and leucocyte elastase in infected and non infected sputum. $A m$ Rev Respir Dis 1979;120:1081-6.

"Stockley RA, Burnett D. Alpha, antichymotrypsin in infected and non infected sputum. Am Rev Respir Dis 1980;122:87-8.

${ }^{12}$ Webb J, Clark TJH, Chilvers C. Time course of response to prednisolone in chronic airflow obstruction. Thorax 1981;36:18-21.

${ }^{13}$ Claman HN. How corticosteroids work. J Allergy Clin Immunol 1975;55:145-51.

${ }_{14}$ Travis J, Bowen J, Baugh R. Human alpha, antichymotrypsin interaction with chymotrypsin-like proteases. Biochemistry 1978;17:5651-6. 